International Journal of Current Advanced Research

ISSN: O: 2319-6475, ISSN: P: 2319 - 6505, Impact Factor: SJIF: 5.995

Available Online at www.journalijcar.org

Volume 6; Issue 3; March 2017; Page No. 2907-2909

DOI: http://dx.doi.org/10.24327/ijcar.2017.2909.0139

Research Article

\title{
ORAL MANIFESTATION ARAISING IN ACTINOMYCOSIS
}

\author{
Mugilan MR* and Dhanaraj
}

Saveetha Dental College \& Hospitals Chennai-600 077

A R T I C L E I N F O

Article History:

Received $15^{\text {th }}$ December, 2016

Received in revised form $24^{\text {th }}$ January, 2017

Accepted $4^{\text {th }}$ February, 2017

Published online $28^{\text {th }}$ March, 2017

\section{Key words:}

Actinomycosis, Oral Manifestation

\begin{abstract}
A B S T R A C T
Aim: To assess knowledge and awareness among the dental students about the oral manifestation arising in actinomycosis

Background: Actinomycosis is a rare infectious bacterial disease caused by Actinomyces species. About 70\% of infections are due to either Actinomyces israelii or A. gerencseriae. Infection can also be caused by other Actinomyces species, as well as Propionibacterium propionicus, which presents similar symptoms. The condition is likely to be polymicrobial aerobic anaerobic infection.

Materials and Methods: The questionnaire included the basic information like the subjects' name, age, sex. All these questionnaires were framed to create awareness about the disease actinomycosis amongst the dental students.

Result: As a result of this study Dental students have to be aware of typical clinical presentations such as actinomycosis. From the above survey it is noted that only $38 \%$ of dental students were aware about this disease.

Conclusion: From the above survey it is noted that only $38 \%$ of dental students were aware about this disease. So creating awareness about this disease is must. Awareness can be created by IEC activities and social media.
\end{abstract}

Copyright $\bigcirc 2017$ Mugilan MR and Dhanaraj. This is an open access article distributed under the Creative Commons Attribution License, which permits unrestricted use, distribution, and reproduction in any medium, provided the original work is properly cited.

\section{INTRODUCTION}

Actinomycosis is a rare infectious bacterial disease caused by Actinomyces species [1]. It is caused due to either Actinomyces israelii or A. gerencseriae. [1], anaerobic Grampositive bacteria that normally colonize the human mouth and digestive and genital tracts.

Actinomycosis is an infrequent invasive bacterial disease that has been recognized for over a century. Actinomyces spp. are filamentous Gram-positive bacilli, mainly belonging to the human commensal flora of the oropharynx, gastrointestinal tract, and urogenital tract. [7] To date, multiple different clinical features of actinomycosis have been described, as various anatomical sites (such as face, bone and joint, respiratory tract, genitourinary tract, digestive tract, central nervous system, skin, and soft tissue structures) can be affected [2]. Of note, in any site, actinomycosis frequently mimics malignancy, tuberculosis, as it spreads continuously and progressively, and often forms a cold abscess. Actinomycosis is unusual in that the infection is able to move slowly but steadily through body tissue [3]. Symptoms of actinomycosis vary depending on the type of infection, but can include, swelling and inflammation of affected tissue, tissue damage that results in scar tissue, formation of

*Corresponding author: Mugilan MR

Saveetha Dental College \& Hospitals Chennai-600 077 abscesses (pus-filled swellings) small holes or tunnels that develop in tissue and leak a type of lumpy pus. The diagnosis of actinomycosis can be a difficult one to make [5][6][8]. In addition to microbiological examinations, magnetic resonance imaging and immunoassays may be helpful [9].

\section{MATERIALS AND METHODS}

The participants for the study included 100 students from first year BDS of Dental Colleges. A questionnaire accessing knowledge and awareness among the dental students about the oral manifestation arising in actinomycosis. This study was a questionnaire based study. The questionnaire was selfadministered. The questionnaire included the basic information like the subjects' name, age, sex. All these questionnaires were framed to create awareness about the disease actinomycosis amongst the dental students. The study group consisted of a total of 100 participants from the city of Chennai (India). Since this study involves only dental students, the participants were aged between 17-19 years. The questionnaire was distributed to the subjects and the responses were collected.

\section{RESULT}

100 students participated in the study. The mean age group with S.D was 20. out of 100 people who are studying dentistry BDS first year in chennai. Now it is quite challenging and disgusting that about only $38 \%$ of them was 
aware about the oral manifestations arising in the disease actinomycosis while rest of the $62 \%$ was not aware about this disease.Its quite surprising that only $12 \%$ of them knows that this disease is greater in males aged between 20-60 than in females while around $8-\%$ of them was not about this fact.Now $43 \%$ of them knows that actinomycosis is caused by the bacterium actinomycosis Israeli while 57\% doesn't know about this.64\% of them knows that actinomycosis affects oral cavity, gastrointestinal tract and lungs while rest of the $36 \%$ doesn't know about this. $39 \%$ of them knows that the disease actinomycosis is characterised by a formation of painful abscesses (lumpy jaws) while about $61 \%$ of them was not aware about it. 27\% knows that the disease actinomycosis contains sulphur granules while rest of $73 \%$ of them doesn't know about it. Here, only $11 \%$ of the peoples knows that sulphur granules are named due to their appearance while the rest $80 \%$ of them was not aware about it. $83 \%$ of them knows that the disease actinomycosis affects patients who had dental works recently while $17 \%$ of them doesn't know about it.58\% of them knows that even poor oral hygiene can also cause actinomycosis while about $42 \%$ of them doesn't know about it. $19 \%$ of them only knows that penicillin is the drug of choice while rest of the $81 \%$ was not aware about it. The questionnaire given to students has variable answers and all the answers were evaluated and represented by the means of piechart.

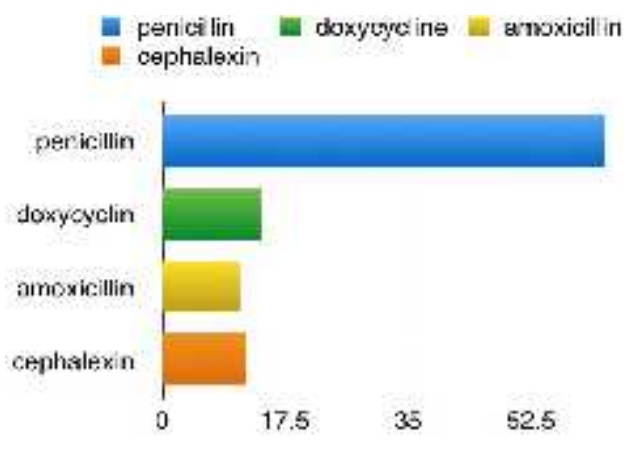

MALES $\mid$ FEMALES $\mid$ I NOT SURE

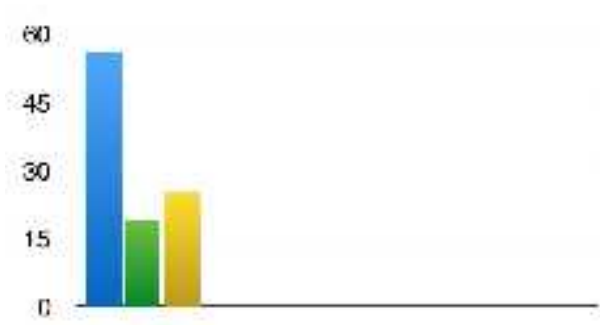

paoples aware about the disease actinomycosis peoples not aware abo.t the disease actinompcosis

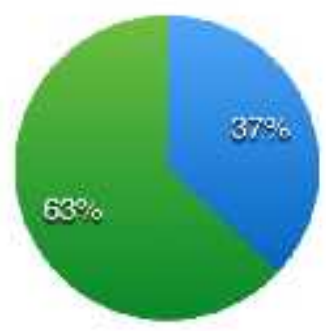

\section{DISCUSSION}

From the above study only $38 \%$ of people was aware about this diseaseobtained from the questionnaire which was distributed to the subjects and the responses were collected.

Similarly, Cone LA awareness of actinomyces odontolyticus bacteria (2003) only $22 \%$ people were aware about this disease actinomycosis. He concluded his study by highlighting the harmful effects caused by the actinomycosis Israeli [6]. In its initial stages, actinomycosis can be a challenging condition to diagnose correctly because it shares symptoms with other more common conditions. It's often only discovered during tests or surgery to check for other conditions.[10][4]. A biopsy is where a small tissue sample is removed so it can be examined under a microscope. For example, many cases of actinomycosis are detected when biopsies are carried out to check for cancer.[13][16].

Actinomycosis can usually be more confidently diagnosed in its later stages, after the sinus tracts have appeared in the surface of the skin.[15] In theory, actinomycosis can develop almost anywhere inside the tissue of the human body.[11][16][14]. Most cases of actinomycosis are thought to be caused by people accidentally inhaling droplets of contaminated fluid into their lungs [5][7][8]. It can develop as a secondary complication of a more common infection, such as appendicitis, or after accidentally swallowing a foreign object, such as a chicken bone. Most cases of pelvic actinomycosis are thought to be associated with the long-term use of an intrauterine device (IUD). In some cases, minor surgery may be required to repair the damaged tissue and drain pus out of the abscesses.[16][12][14]. An initial course of antibiotic injections is usually recommended for 2 to 6 weeks, followed by antibiotic tablets for another 6 to 12 months.[4][3][10]. The preferred antibiotics for treating actinomycosis are benzylpenicillin, which is used for the antibiotic injections, and amoxicillin tablets.[6][7]. Side effects of these antibiotics include diarrhoea,nausea (feeling sick), skin rash, increased vulnerability to fungal infections, such as oral thrush (a fungal infection that occurs in the mouth)[9][11]. If the patient was allergic to penicillin, alternative antibiotics such as tetracycline or erythromycin can be used [13]. If the original site of the infection is mouth, it may spread to tongue, larynx (voicebox), trachea (windpipe) and salivary glands, and the tubes that connect throat to nose. If the infection spreads to brain, a brain abscess could develop. Patients with actinomycosis require prolonged (6- to 12-month) high doses of penicillin G or amoxicillin, but the duration of antimicrobial therapy could likely be reduced (3 months) for patients in whom optimal surgical resection of infected tissues has been performed.[15]

\section{CONCLUSION}

As a result of this studyDental students have to be aware of typical clinical presentations such as actinomycosis.From the above survey it is noted that only $38 \%$ of dental students were aware about this disease.so creating awareness about this disease is must. Awareness can be created by IEC activitiesand social media.

\section{Reference}

1. Wong VK, Turmezei TD, Weston VC. Actinomycosis. BMJ. 2011; 343:d6099. [PubMed] 
2. Smego RA, Jr, Foglia G. Actinomycosis. Clin Infect Dis. 1998; 26(6):1255-1261. [PubMed]

3. Mandell GL, Bennett JE, Dolin R, editors. Mandell, Douglas, and Bennett's Principles and Practice of Infectious Diseases. 7th ed. Philadelphia, PA: Churchill Livingstone Elsevier; 2010.

4. Schaal KP, Lee HJ. Actinomycete infections in humans -a review. Gene. 1992; 115(1-2):201-211. [PubMed]

5. Pulverer G, Schütt-Gerowitt H, Schaal KP. Human cervicofacial actinomycoses: microbiological data for 1997 cases. Clin Infect Dis. 2003; 37(4):490-497. [PubMed]

6. Eng RH, Corrado ML, Cleri D, Cherubin C, Goldstein EJ. Infections caused by Actinomyces viscosus. Am J Clin Pathol. 1981;75(1):113-116. [PubMed]

7. Fazili T, Blair D, Riddell S, Kiska D, Nagra S. Actinomyces meyeri infection: case report and review of the literature. $J$ Infect. 2012;65(4):357-361. [PubMed]

8. Coleman RM, Georg LK, Rozzell AR. Actinomyces naeslundii as an agent of human actinomycosis. Appl Microbiol. 1969;18(3):420-426. [PMC free article] [PubMed]

9. Cone LA, Leung MM, Hirschberg J. Actinomyces odontolyticus bacteremia. Emerg Infect Dis. 2003;9 (12):1629-1632. [PubMed]
10. Sabbe LJ, Van De Merwe D, Schouls L, Bergmans A, Vaneechoutte M, Vandamme P. Clinical spectrum of infections due to the newly described Actinomyces species A. turicensis, A. radingae, and A. europaeus. $J$ Clin Microbiol. 1999; 37(1):8-13. [PMC free article] [PubMed]

11. Clarridge JE, 3rd, Zhang Q. Genotypic diversity of clinical Actinomyces species: phenotype, source, and disease correlation among genospecies. $J$ Clin Microbiol. 2002; 40(9):3442-3448. [PMC free article] [PubMed]

12. Felz MW, Smith MR. Disseminated actinomycosis: multisystem mimicry in primary care. South Med J. 2003; 96(3):294-299. [PubMed]

13. Jordan HV, Kelly DM, Heeley JD. Enhancement of experimental actinomycosis in mice by Eikenella corrodens. Infect Immun. 1984; 46(2):367-371. [PMC free article] [PubMed]

14. Glahn M. Cervico-facial actinomycosis; etiology and diagnosis. Acta Chir Scand. 1954; 108(2-3):183-192. [PubMed]

15. Holm P. Studies on the aetiology of human actinomycosis. II. Do the other microbes of actinomycosis possess virulence? Acta Pathol Microbiol Scand. 1951;28(4):391-406. [PubMed]

16. Lewis R, McKenzie D, Bagg J, Dickie A. Experience with a novel selective medium for isolation of Actinomyces spp. from medical and dental specimens. J Clin Microbiol. 1995;33(6):1613-1616. [PMC free article] [PubMed]

\section{How to cite this article:}

Mugilan MR and Dhanaraj (2017) 'Oral Manifestation Araising In Actinomycosis', International Journal of Current Advanced Research, 06(03), pp. 2907-2909.

DOI: http://dx.doi.org/10.24327/ijcar.2017.2909.0139 